\title{
FAKTOR DETERMINAN MINAT BERWIRAUSAHA MAHASISWA (EVALUASI PEMBELAJARAN KEWIRAUSAHAAN DI PERGURUAN TINGGI PERIKANAN DAN KELAUTAN)
}

\author{
Muh. Ikramullah' ${ }^{1}$ Aslinda ${ }^{2}$, Heriansah $^{1}$ \\ ${ }^{1}$ Sekolah Tinggi Teknologi Kelautan Makassar, Jl. Perintis Kemerdekaan VIII No. 8, Makassar, \\ 90245, Indonesia \\ 2Fakultas Ilmu Sosial, Universitas Negeri Makassar, Jl. A.P Pettarani, Makassar, 90222, \\ Indonesia
}

Email: heriansah@stitek-balikdiwa.ac.id

\begin{abstract}
ABSTRAK
Pembelajaran kewirausahaan di perguruan tinggi memiliki peran strategis dalam mengembangkan minat berwirausaha mahasiswa. Penelitian ini bertujuan untuk mengetahui faktor determinan minat berwirausaha mahasiswa sebagai bahan evaluasi pembelajaran kewirausahaan, khususnya di perguruan tinggi perikanan dan kelautan. Penelitian ini menggunakan pendekatan kuantitatif melalui metode deskriptif korelasional. Jumlah responden sebanyak 110 mahasiswa Sekolah Tinggi Teknologi Kelautan (STITEK) Balik Diwa Makassar. Data dikumpulkan melalui instrumen kuesioner dengan menggunakan skala Likert dan dianalisis dengan menggunakan analisis regresi berganda. Hasil penelitian menunjukkan bahwa 43,6\% minat berwirausaha mahasiswa secara simultan dipengaruhi oleh faktor ekspektasi pendapatan $\left(X_{1}\right)$, dukungan keluarga $\left(X_{2}\right)$, dan pembelajaran kewirausahaan $\left(X_{3}\right)$. Persamaan regresi minat berwirausaha mahasiswa adalah $Y=1,112+0,302 X_{1}+$ $0,736 \mathrm{X}_{2}+0,284 \mathrm{X}_{3}$. Ekspektasi pendapatan dan lingkungan keluarga serta pembelajaran kewirausahaan secara bersama-sama mempengaruhi minat responden untuk berwirausaha $(\mathrm{P}<0,05)$. Pembelajaran kewirausahaan memberikan kontribusi terendah terhadap minat berwirausaha mahasiswa. Metode dan fasilitas pembelajaran perlu mendapatkan perhatian khusus dalam meningkatkan minat berwirausaha mahasiswa. Metode dan fasilitas pembelajaran kewirausahaan harus mampu menumbuhkembangan jiwa dan aktivitas kewirausahaan yang berbasis aktivitas lingkungan keluarga yang didukung oleh ilmu pengetahuan dan teknologi.
\end{abstract}

Kata kunci: ekspektasi pendapatan, lingkungan keluarga, minat berwirausaha, pembelajaran kewirausahaan, perikanan dan kelautan 


\begin{abstract}
Entrepreneurship learning in higher education has a strategic role in developing students' interest in entrepreneurship. This study aims to determine the determinant factors of student interest in entrepreneurship as an evaluation material for entrepreneurship learning, especially in fisheries and marine colleges. This study uses a quantitative approach through descriptive correlational methods. The number of respondents was 110 students of the College Marine Technology of Balik Diwa Makassar. The data were collected through a questionnaire instrument using a Likert scale and analyzed using multiple regression analysis. The results showed that $43.6 \%$ of students' interest in entrepreneurship was simultaneously influenced by factors of income expectations $\left(X_{1}\right)$, family support $\left(X_{2}\right)$, and entrepreneurial learning $\left(X_{3}\right)$. The regression equation for student interest in entrepreneurship is $Y=1.112+0.302 X 1+$ $0.736 \mathrm{X} 2+0.284 X 3$. Income expectations and family support as well as entrepreneurial learning together influence respondents' interest in entrepreneurship $(P<0.05)$. Entrepreneurship learning provided the lowest contribution to student entrepreneurial interest. Learning methods and facilities need special attention in increasing student entrepreneurial interest. These entrepreneurial learning methods and facilities must be able to develop entrepreneurial spirit and activities based on family environment activities supported by science and technology.
\end{abstract}

Keywords: entrepreneurship learning, family environment, fisheries and marine, income expectations, interest in entrepreneurship

\section{PENDAHULUAN}

Bonus demografi sebagai fenomena transisi demografis telah menjadi isu strategis di Indonesia. Transisi demografis yang hanya terjadi sekali saja dalam sebuah negara dicirikan oleh meningkatnya jumlah penduduk usia produktif bekerja (15-64 tahun) sebanyak dua kali lipat yang diiringi oleh menurunnya jumlah usia lanjut (di atas 64 tahun) dan tertundanya pertumbuhan usia muda (di bawah 15 tahun) sehingga jumlah penduduk usia produktif lebih banyak dibandingkan usia tidak produktif (Jati, 2015; Maryati, 2015).

Bonus demografi bagaikan dua sisi mata uang, dimana satu sisi dapat menjadi potensi jika penduduk yang berusia produktif mampu menciptakan pendapatan dan investasi, tetapi disisi lain dapat menjadi ancaman jika penduduk usia produktif tersebut tidak bekerja yang dapat memicu munculnya berbagai permasalahan ekonomi, sosial, dan hukum. Oleh karena itu, perlu upaya yang sistematis dalam mempersiapkan sumberdaya manusia yang produktif pada usia produktifnya.

Salah satu upaya untuk mempersiapkan sumberdaya produktif adalah pembelajaran kewirausahaan. Tujuan pembelajaran kewirausahaan adalah membekali pemahaman teori dan praktis wirausaha sehingga orientasi mahasiswa setelah menyelesaikan studi tidak hanya sebagai pencari kerja tetapi pencipta kerja (Suarjana dan Wahyuni, 2017; Utami, 2017; Listiawati dkk., 2020). Pertumbuhan kewirausahaan pada sebuah negara ditentukan oleh kontribusi perguruan tinggi melalui 
pembelajaran kewirausahaan (Utami, 2017; Zimmerer dkk., 2002). Perguruan tinggi di Indonesia telah banyak menyadari pentingnya pembelajaran kewirausahaan untuk menciptakan wirausaha muda (Permatasari dan Agustina, 2018). Pada konteks kekinian dimana pandemi Covid-19 berdampak terhadap menurunnya jumlah lapangan pekerjaan, maka pembelajaran dan aktivitas kewirausahaan semakin penting dikembangkan.

Hal yang sangat penting dalam pembelajaran kewirausahaan di perguruan tinggi adalah menumbuhkembangkan minat mahasiswa untuk berwirausaha. Minat merupakan sebuah hasrat dan antusias serta perhatian individu yang tinggi terhadap sesuatu hal yang disertai dengan keinginan untuk mengetahui dan membuktikan lebih lanjut melalui serangkaian aktivitas (Syah, 2001; Walgito, 2004; Djaali, 2012).

Minat berwirausaha menurut Alma (2016) dipengaruhi oleh tiga faktor, yaitu: (1) faktor kepribadian (ketidakpuasan, keberanian, tidak ada pekerjaan lain, usia, dan komitmen), (2) faktor lingkungan (persaingan, sumberdaya, pelatihan, dan kebijakan pemerintah), dan (3) faktor keluarga (relasi, dorongan orang tua, bantuan keluarga, dan pengalaman). Sutanto (2002) dan Hantoro (2005) menggolongkan dua faktor yang dapat mempengaruhi minat berwirausaha, yaitu: (1) faktor dari dalam diri sendiri (intristik), seperti pendapatan, harga diri, dan perasaan senang, dan (2) faktor dari luar diri (ekstrinsik), seperti lingkungan keluarga, masyarakat, peluang, sarana, serta pengetahuan dan keterampilan.
Beberapa penelitian melaporkan bahwa faktor pembelajaran kewirausahaan, lingkungan keluarga, dan ekspektasi pendapatan dapat mempengaruhi minat mahasiswa untuk berwirausaha (Azzam, 2016; Fahmi dan Amanda, 2017; Suarjana dan Wahyuni, 2017; Aryaningtyas dan Palupiningtyas, 2017; Pujiastuti dan Filantrovi, 2018; Listiawati, dkk., 2020). Penelitian tersebut dilakukan terhadap mahasiswa pada bidang ilmu non perikanan dan kelautan. Penelitian tentang faktor yang mempengetahui minat berwirausaha mahasiswa pada bidang ilmu perikanan dan kelautan sejauh ini masih sangat terbatas.

Khusus bagi perguruan tinggi yang pada bidang ilmu perikanan dan kelautan, pembelajaran kewirausahaan adalah sesuatu yang mutlak. Potensi perikanan dan kelautan Indonesia yang besar merupakan peluang bisnis kewirausahaan. Karakteristik khas produk perikanan dan kelautan yang berisiko tinggi menuntut intervensi ilmu pengetahuan dan teknologi dalam pengelolaannya. Oleh karena itu, pengetahuan dan keterampilan yang diperoleh oleh mahasiswa selama kuliah diharapkan dapat menjadi modal dasar untuk menjadi seorang wirausahawan atau entrepreneur perikanan pada saat dan/atau setelah menyelesaikan studinya.

Berdasarkan uraian diatas, perlu kajian faktor determinan minat berwirausaha mahasiswa perikanan dan kelautan. Tujuan penelitian ini adalah untuk mengkaji faktor determinan mahasiswa perikanan dan kelautan dalam berwirausaha. 
Urgensi penelian ini dapat menjadi salah satu bahan evaluasi terhadap pembelajaran kewirausahaan di perguruan tinggi pada bidang ilmu perikanan dan kelautan pada umumnya dan Sekolah Tinggi Teknologi Kelautan (STITEK) Balik Diwa Makassar pada khususnya.

\section{METODE}

Penelitian dilaksanakan pada bulan Agustus sampai dengan Oktober 2020. Penelitian ini menggunakan pendekatan kuantitatif melalui metode deskriptif korelasional. Oleh karena banyak faktor yang mempengaruhi minat berwirausaha mahasiswa, penelitian ini hanya membatasi pada beberapa variabel saja dengan mengacu pada beberapa penelitian yang telah dilakukan pada mahasiswa bidang ilmu non perikanan dan kelautan. Berdasarkan hal tersebut, maka variabel pada penelitian ini terdiri dari minat berwirausaha sebagai variabel terikat $(\mathrm{Y})$ dan ekspektasi pendapatan $\left(\mathrm{X}_{1}\right)$, lingkungan keluarga $\left(\mathrm{X}_{2}\right)$, dan pembelajaran kewirausahaan $\left(X_{3}\right)$ sebagai variabel bebas.

Populasi pada penelitian ini adalah mahasiswa aktif STITEK Balik Diwa Makassar yang telah melulusi mata kuliah kewirausahaan yang berjumlah 152 mahasiswa. Mengacu pada Rumus Slovin (Sugiyono, 2011), maka jumlah sampel yang menjadi responden sebanyak 110 mahasiswa. Sampel tersebut adalah mahasiswa semester 6 dan 8 dari Program Studi Budidaya Perairan (BDP), Teknologi Hasil Perikanan (THP), Pemanfaatan Sumberdaya Perairan (PSP), dan Ilmu Kelautan (IK).
Data dikumpulkan dengan melalui instrumen kuesioner (online). Kuesioner menggunakan skala Likert dengan skor 1 (Sangat Tidak Setuju), 2 (Tidak Setuju), 3 (Netral), 4 (Setuju), dan 5 (Sangat Setuju). Hasil uji validitas dan reliabilitas kuesioner disajikan pada Tabel 1 dan Tabel 2.

Tabel 1. Hasil uji validitas instrumen

\begin{tabular}{lcc}
\hline \multicolumn{1}{c}{ Variabel / Item } & $\begin{array}{c}\text { Pearson } \\
\text { Correlation }\end{array}$ & Ket. \\
\hline $\begin{array}{l}\text { Ekspektasi } \\
\text { pendapatan (1-5) }\end{array}$ & $0.480-0.807$ & Valid \\
$\begin{array}{l}\text { Lingkungan keluarga } \\
(6-10)\end{array}$ & $0.634-0.805$ & Valid \\
$\begin{array}{l}\text { Pembelajaran kewira- } \\
\text { usahaan (11-25) }\end{array}$ & $0.352-0.820$ & Valid \\
$\begin{array}{l}\text { Minat berwirausaha } \\
\text { (26-35) }\end{array}$ & $0.438-0.815$ & Valid \\
\hline $\begin{array}{l}\text { Keterangan: Jika nilai Pearson Correlation } \\
\text { instrumen dinyatatakan valid }\end{array}$ & & \\
\hline
\end{tabular}

Tabel 2. Hasil uji reliabilitas

\begin{tabular}{|c|c|c|}
\hline Variabel & $\begin{array}{l}\text { Cronbach's } \\
\text { Alpha }\end{array}$ & Ket. \\
\hline Ekspektasi pendapatan & 0.737 & Reliabel \\
\hline Lingkungan keluarga & 0.745 & Reliabel \\
\hline $\begin{array}{l}\text { Pembelajaran } \\
\text { kewirausahaan }\end{array}$ & 0.873 & Reliabel \\
\hline Minat berwirausaha & 0.839 & Reliabel \\
\hline
\end{tabular}

Hasil uji validitas dan reliabilitas kuesioner pada Tabel 1 dan Tabel 2 menunjukkan bahwa semua item pernyataan pada instrumen yang digunakan dinyatakan valid dan reliabel. Instrumen kuesioner yang valid dan reliabel memiliki kesahihan dan keandalan yang tinggi sehingga data yang dikumpulkan dapat dipercaya (Sugiyono, 2011).

Analisis data yang digunakan pada penelitian ini adalah regresi berganda: $Y=a+b_{1} X_{1}+b_{2} X_{2}+b_{3} X_{3}$. Hasil uji prayarat model regresi disajikan pada tabel berikut ini: 
Tabel 3. Hasil uji normalitas

\begin{tabular}{llr}
\multicolumn{2}{c}{ One-Sample Kolmogorov-Smirnov Test } \\
\hline & & Standardized Residual \\
\hline $\mathrm{N}$ & & 110 \\
\hline Normal & Mean & .0000000 \\
Parameters & \\
& Std. Deviation & .98614252 \\
Kolmogorov-Smirnov Z & .874 \\
Asymp. Sig. (2-tailed) & .429 \\
\hline
\end{tabular}

a. Test distribution is Normal

Tabel 4. Hasil uji Heteroskedastisitas

\begin{tabular}{|c|c|c|}
\hline \multicolumn{3}{|c|}{ Coefficients $^{\mathrm{a}}$} \\
\hline Model & $\mathrm{t}$ & Sig. \\
\hline 1 (Constant) & 2.293 & .024 \\
\hline Ekspektasi_Pendapatan & -1.424 & .157 \\
\hline Lingkungan_Keluarga & 1.205 & .231 \\
\hline $\begin{array}{l}\text { Pembelajaran_ } \\
\text { Kewirausahaan }\end{array}$ & -.844 & .401 \\
\hline
\end{tabular}

a. Dependent Variable: ABSResid

Tabel 5. Hasil uji linearitas

\begin{tabular}{|c|c|c|c|}
\hline \multicolumn{4}{|c|}{ ANOVA Table } \\
\hline & & & Sig. \\
\hline \multirow{3}{*}{$\begin{array}{l}\text { Minat_- } \\
\text { Berwirausaha * } \\
\text { Ekspektasi__ } \\
\text { Pendapatan }\end{array}$} & \multirow{3}{*}{$\begin{array}{l}\text { Between } \\
\text { Groups }\end{array}$} & (Combined) & .000 \\
\hline & & Linearity & .000 \\
\hline & & $\begin{array}{l}\text { Deviation from } \\
\text { Linearity }\end{array}$ & .354 \\
\hline \multirow{3}{*}{$\begin{array}{l}\text { Minat__ } \\
\text { Berwirausaha * } \\
\text { Lingkungan_- } \\
\text { Keluarga }\end{array}$} & \multirow{3}{*}{$\begin{array}{l}\text { Between } \\
\text { Groups }\end{array}$} & (Combined) & .000 \\
\hline & & Linearity & .000 \\
\hline & & $\begin{array}{l}\text { Deviation from } \\
\text { Linearity }\end{array}$ & .372 \\
\hline \multirow{3}{*}{$\begin{array}{l}\text { Minat_ } \\
\text { Berwirausaha * } \\
\text { Pembelajaran_ } \\
\text { Kewirausahaan }\end{array}$} & \multirow{3}{*}{$\begin{array}{l}\text { Between } \\
\text { Groups }\end{array}$} & (Combined) & .000 \\
\hline & & Linearity & .000 \\
\hline & & $\begin{array}{l}\text { Deviation from } \\
\text { Linearity }\end{array}$ & .559 \\
\hline
\end{tabular}

Tabel 6. Hasil uji multikolinearitas

\begin{tabular}{|c|c|c|c|}
\hline \multicolumn{4}{|c|}{ Coefficients $^{a}$} \\
\hline & & \multicolumn{2}{|c|}{ Collinearity Statistics } \\
\hline \multicolumn{2}{|c|}{ Model } & Tolerance & VIF \\
\hline \multirow[t]{3}{*}{1} & (Constant) & & \\
\hline & $\begin{array}{l}\text { Ekspektasi_- } \\
\text { Pendapatan }\end{array}$ & .600 & 1.667 \\
\hline & $\begin{array}{l}\text { Lingkungan } \\
\text { Keluarga }\end{array}$ & .603 & 1.657 \\
\hline
\end{tabular}

\begin{tabular}{lll}
$\begin{array}{l}\text { Pembelajaran_ } \\
\text { Kewirausahaan }\end{array}$ & .602 & 1.661 \\
\hline a. Dependent Variable: ABSResid & &
\end{tabular}

Hasil uji normalitas pada Tabel 3 menunjukkan nilai Asymp Sig 0.429 diatas 0.05 yang berarti data berdistribusi normal. Hasil uji Heteroskedastisitas pada Tabel 4 menunjukkan nilai Sig. variabel ekspektasi pendapatan 0,157, lingkungan keluarga 0,231, dan pembelajaran kewirausahaan 0,401 masing-masing diatas 0,05 yang berarti tidak ada gejala heteroskedastisitas data. Hasil uji linearitas pada Tabel 5 menunjukkan nilai Sig. Deviation from Linearity ekspektasi pendapatan terhadap minat berwirausaha 0,354, lingkungan keluarga 0,372, dan pembelajaran kewirausahaan 0,559 masing-masing di atas 0,05 yang berarti hubungan antara variabel bebas dan variabel terikat bersifat linier. Hasil uji multikolinearitas data pada Tabel 6 menunjukkan nilai tolerance variabel ekspektasi pendapatan 0,600, lingkungan keluarga 0,603, dan variabel pembelajaran kewirausahaan 0.602 masing-masing diatas 0,10 sehingga tidak terdapat multikolinearitas antar variabel. Hasil semua uji prasyarat model regresi dengan sumsi klasik ini mengindikasikan bahwa data yang digunakan memenuhi persyaratan penggunaan regresi.

\section{HASIL DAN PEMBAHASAN}

\section{Deskripsi Data Responden}

Karakteristik responden disajikan pada Gambar 1 berikut ini: 


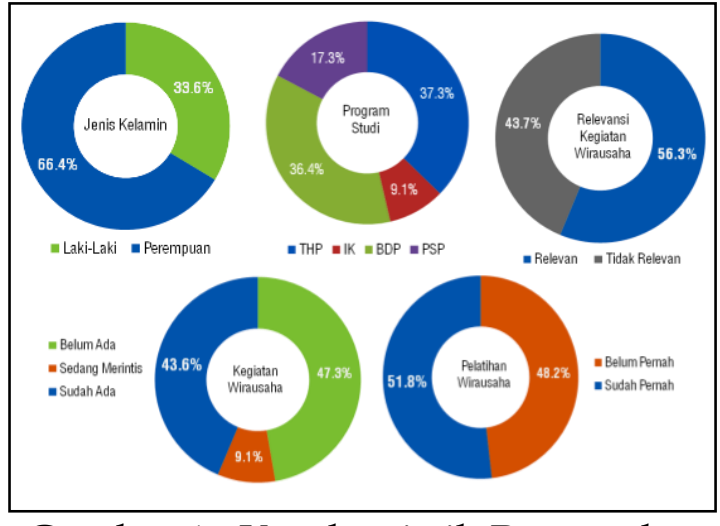

Gambar 1. Karakteristik Responden

Karakteristik

berdasarkan jenis kelamin menunjukkan bahwa dari 110 responden, $73(66,4 \%)$ adalah perempuan dan $37(33,6 \%)$ adalah laki-laki. Mayoritas perempuan sebagai responden pada penelitian ini merupakan representasi dari komposisi jenis kelamin mahasiswa STITEK Balik Diwa Makassar. Responden juga tersebar berdasarkan program studi, dimana $41 \quad(37,3 \%)$ THP, 40 (36,4\%) BDP, 19 (17,3\%) PSP, dan $10(9,1 \%)$.

Karakteristik responden berdasarkan ada tidaknya kegiatan wirausaha yang dilaksanakan saat ini menunjukkan bahwa dari 110 responden, $48(43,6 \%)$ diantaranya sedang menjalankan wirausaha, 52 $(47,3 \%)$ belum berwirausaha, dan 10 $(9,1 \%)$ responden yang sementara dalam tahap merintis kegiatan kewirausahaan. Jenis wirausaha yang dijalankan oleh 48 responden yang sedang berwirausaha relatif beragam, 27 (56,3\%) memiliki relevansi dengan bidang ilmu yang ditekuninya dan 21 (43,7\%) kurang relevan. Beberapa jenis wirausaha yang relevan antara lain budidaya minapadi, budidaya ikan hias dan ikan bandeng, pembuatan akuaponik, pengolahan dan pemasaran produk perikanan, seperti teripang laut segar dan olahan, telur ikan terbang, ikan bandeng, garam, serta usaha homestay wisata pulau. Jenis wirausaha yang kurang relevan antara lain beternak sapi, penjualan online produk fashion, pemasaran dan pengolahan kripik singkong, gula merah, jagung, jahe, kayu/bambu, dan usaha percetakan (sablon). Umumnya kegiatan wirausaha yang kurang relevan tersebut merupakan usaha orang tua dan keluarga yang dilanjutkan oleh responden. Beberapa responden sementara merintis wirausaha yang umumnya adalah usaha penjualan online produk makanan siap saji.

Karakteristik

responden

berdasarkan kegiatan pelatihan menunjukkan bahwa dari 110 responden, $57(51,8 \%)$ sudah pernah mengikuti dan $53(48,2 \%)$ responden belum pernah mengikuti pelatihan dan/atau seminar kewirausahaan. 57 responden yang pernah mengikuti pelatihan dan/atau seminar kewirausahaan, 35 (61,4\%) diantaranya telah menjalankan kegiatan wirausaha, 7 $(12,3 \%)$ responden sementara dalam tahap perintisan wirausaha, dan selebihnya $15 \quad(26,3 \%)$ responden belum menjalankan atau merintis kegiatan wirausaha. 53 responden yang belum pernah mengikuti pelatihan dan/atau seminar kewirausahaan umumnya yaitu 38 (71,7\%) belum menjalankan atau merintis kegiatan wirausaha, $12(22,6 \%)$ telah berwirausaha, dan hanya $3(5,7 \%)$ yang sementara merintis kegiatan wirausaha. Kondisi ini menunjukkan bahwa ternyata tidak semua mahasiswa yang pernah mengikuti pelatihan dan/atau seminar 
kewirausahaan telah menjalankan wirausaha, demikian pula sebaliknya.

\section{Deskripsi Variabel Penelitian}

\subsection{Ekspektasi pendapatan}

Variabel ekspektasi pendapatan terdiri dari beberapa indikator, antara lain jumlah pendapatan seorang wirausaha, pendapatan sebagai motivasi berwirausaha, dan jaminan masa depan dari wirausaha. Ketiga indikator tersebut direpresentasikan melalui 5 pernyataan. Hasil analisis deskriptif variabel ekspektasi pendapatan pada Tabel 7 menunjukkan bahwa rata-rata empirik sebesar 20,53 dan standar deviasi empirik sebesar 1,971. Berdasarkan skor maksimal (5) dan minimal (1) item serta jumlah item pernyataan (5), diperoleh rata-rata hipotetik sebesar 15,00. Data ini menunjukkan bahwa rata-rata empirik lebih besar dibandingkan rata-rata hipotetik yang berarti ekspektasi responden terhadap pendapatan dari kegiatan kewirausahaan cenderung tinggi (positif). Namun demikian, berdasarkan skor maksimal (24) dan minimal (16) subjek diperoleh standar deviasi hipotetik sebesar 1,333 yang lebih rendah daripada standar deviasi empirik yang berarti bahwa ekspektasi para responden tersebut memiliki variasi yang tinggi atau cenderung tidak seragam. Dengan kata lain, ada beberapa responden yang memiliki ekspektasi yang tinggi dan ada juga yang rendah. Hasil pengkategorian berdasarkan metode Azwar (2012) menunjukkan bahwa ekspektasi 110 responden terhadap pendapatan dari kegiatan wirausaha umumnya pada kategori "sedang" $(40,0 \%)$. Hasil tersebut memberikan indikasi bahwa penilaian responden terhadap jumlah pendapatan seorang wirausaha, pendapatan sebagai motivasi berwirausaha, dan jaminan masa depan dari wirausaha masih berada pada kategori "sedang" dalam meningkatkan minat berwirausaha.

Tabel 7. Hasil analisis deskriptif variabel ekspektasi pendapatan

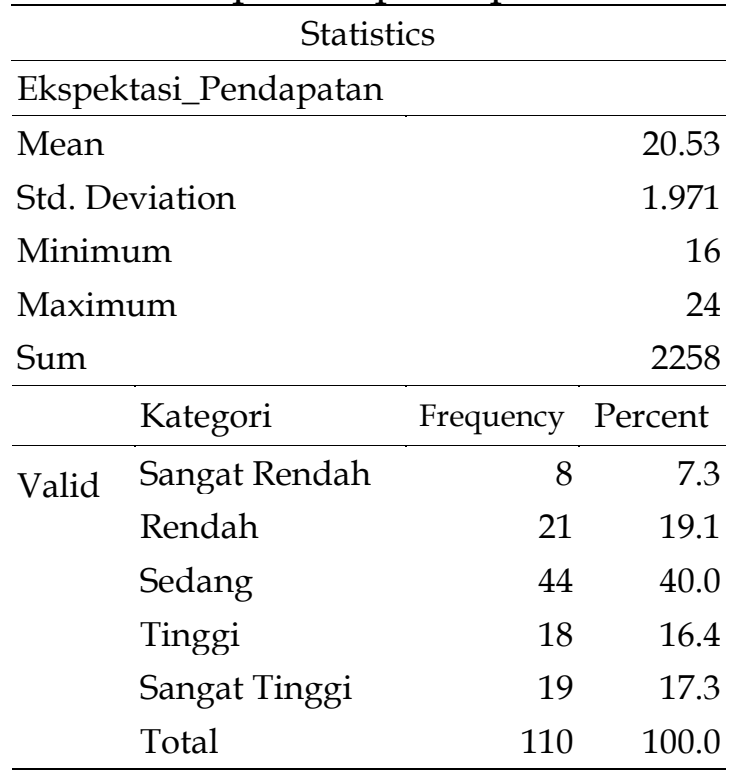

\subsection{Lingkungan keluarga}

Variabel lingkungan keluarga terdiri dari indikator dukungan dan ekonomi keluarga keluarga, serta didikan orangtua berwirausaha yang direpresentasikan melalui 5 pernyataan.

Tabel 8. Hasil analisis deskriptif variabel lingkungan keluarga

\begin{tabular}{lr}
\hline \multicolumn{2}{c}{ Statistics } \\
\hline Lingkungan_Keluarga \\
\hline Mean & 20.50 \\
Std. Deviation & 2.022 \\
Minimum & 15 \\
Maximum & 25 \\
Sum & 2255 \\
\hline
\end{tabular}




\begin{tabular}{llrr}
\hline Kategori & Frequency & Percent \\
\hline \multirow{2}{*}{ Valid } & Sangat Rendah & 2 & 1.8 \\
& Rendah & 15 & 13.6 \\
Sedang & 58 & 52.7 \\
Tinggi & 25 & 22.7 \\
Sangat Tinggi & 10 & 9.1 \\
Total & 110 & 100.0 \\
\hline
\end{tabular}

Mengacu pada Tabel 8 diperoleh rata-rata empirik sebesar 20,50 dan standar deviasi empirik sebesar 2,022. Berdasarkan skor maksimal (5) dan minimal (1) item serta jumlah item pernyataan (5), diperoleh rata-rata hipotetik sebesar 15,00. Data ini menunjukkan bahwa rata-rata empirik lebih besar dibandingkan rata-rata hipotetik yang berarti bahwa dukungan keluarga terhadap kegiatan kewirausahaan responden memiliki kecenderungan yang tinggi (positif). Namun demikian, berdasarkan skor maksimal (25) dan minimal (15) subjek diperoleh standar deviasi hipotetik sebesar 1,667 yang lebih rendah daripada standar deviasi empirik yang berarti bahwa dukungan lingkungan keluarga terhadap kegiatan kewirausahaan responden memiliki variasi yang tinggi atau cenderung tidak seragam. Dengan kata lain, ada beberapa responden yang mempunyai dukungan lingkungan keluarga yang tinggi dan ada juga yang rendah. Hasil pengkategorian menunjukkan bahwa dukungan lingkungan keluarga 110 responden untuk kegiatan wirausaha umumnya pada kategori "sedang" (52,7\%). Hasil tersebut memberikan indikasi bahwa penilaian responden terhadap dukungan dan ekonomi keluarga keluarga serta didikan orangtua untuk berwirausaha masih berada pada kategori "sedang" dalam meningkatkan minat berwirausaha.

\subsection{Pembelajaran kewirausahaan}

Variabel pembelajaran kewirausahaan terdiri dari beberapa indikator, antara lain pengetahuan dan motivasi, antusias, metode pembelajaran, kapasitas dosen, dan fasilitas pembelajaran. Ketujuh indikator tersebut direpresentasikan melalui 15 pernyataan. Hasil analisis deskriptif variabel pembelajaran kewirausahaan pada Tabel 7 menunjukkan bahwa rata-rata empirik sebesar 61,18 dan standar deviasi empirik sebesar 6,464. Data ini menunjukkan bahwa rata-rata empirik lebih besar dibandingkan rata-rata hipotetik yang berarti bahwa dampak pembelajaran kewirausahaan terhadap kegiatan kewirausahaan responden cenderung tinggi (positif).

Tabel 9. Hasil analisis deskriptif variabel pembelajaran kewirausahaan

\begin{tabular}{|c|c|c|c|}
\hline \multicolumn{4}{|c|}{ Statistics } \\
\hline \multicolumn{4}{|c|}{ Pembelajaran_Kewirausahaan } \\
\hline \multicolumn{2}{|c|}{ Mean } & & 61.18 \\
\hline \multicolumn{2}{|c|}{ Std. Deviation } & & 6.464 \\
\hline \multicolumn{2}{|c|}{ Minimum } & & 45 \\
\hline \multicolumn{2}{|c|}{ Maximum } & & 75 \\
\hline \multirow[t]{2}{*}{ Sum } & & & 6730 \\
\hline & Kategori & Frequency & Percent \\
\hline \multirow[t]{6}{*}{ Valid } & Sangat Rendah & 4 & 3.6 \\
\hline & Rendah & 28 & 25.5 \\
\hline & Sedang & 38 & 34.5 \\
\hline & Tinggi & 30 & 27.3 \\
\hline & Sangat Tinggi & 10 & 9.1 \\
\hline & Total & 110 & 100.0 \\
\hline
\end{tabular}

Berdasarkan skor maksimal (75) dan minimal (45) subjek diperoleh standar deviasi hipotetik sebesar 5,000 yang lebih rendah daripada standar 
deviasi empirik yang berarti bahwa dampak pembelajaran terhadap kegiatan kewirausahaan responden memiliki variasi yang tinggi atau cenderung tidak seragam. Dengan kata lain, ada beberapa responden yang merasakan dampak yang tinggi dan ada juga yang rendah. Hasil pengkategorian menunjukkan bahwa dampak mata kuliah kewirausahaan dari 110 responden terhadap kegiatan wirausaha umumnya pada kategori "sedang" (34,5\%). Hasil tersebut memberikan indikasi bahwa penilaian responden terhadap pengetahuan dan motivasi, antusias, metode pembelajaran, kapasitas dosen, dan fasilitas pembelajaran masih berada pada kategori "sedang" dalam meningkatkan minat berwirausaha.

\subsection{Minat berwirausaha}

Variabel minat berwirausaha terdiri dari beberapa indikator, antara lain pengetahuan dan motivasi yang diperoleh, antusias, praktek dan seminar, metode pembelajaran, dosen, dan fasilitas pembelajaran mata kuliah kewirausahaan. Ketujuh indikator tersebut direpresentasikan melalui 10 pernyataan.

Tabel 10. Hasil analisis deskriptif variabel minat berwirausaha

\begin{tabular}{|c|c|c|c|}
\hline \multicolumn{4}{|c|}{ Statistics } \\
\hline \multicolumn{4}{|c|}{ Minat_Berwirausaha } \\
\hline \multicolumn{3}{|l|}{ Mean } & 39.75 \\
\hline \multicolumn{3}{|c|}{ Std. Deviation } & 5.058 \\
\hline \multicolumn{3}{|c|}{ Minimum } & 28 \\
\hline \multicolumn{3}{|c|}{ Maximum } & 50 \\
\hline \multicolumn{3}{|l|}{ Sum } & 4372 \\
\hline & Kategori & Frequency & Percent \\
\hline \multirow[t]{3}{*}{ Valid } & Sangat Rendah & 5 & 4.5 \\
\hline & Rendah & 23 & 20.9 \\
\hline & Sedang & 44 & 40.0 \\
\hline
\end{tabular}

\begin{tabular}{lrr} 
Tinggi & 26 & 23.6 \\
Sangat Tinggi & 12 & 10.9 \\
Total & 110 & 100.0 \\
\hline Mengacu pada & Tabel & 10
\end{tabular}
diperoleh rata-rata empirik sebesar 39,75 dan standar deviasi empirik sebesar 5,058. Berdasarkan skor maksimal (5) dan minimal (1) item serta jumlah item pernyataan (10), diperoleh rata-rata hipotetik sebesar 30,00. Hal ini menunjukkan bahwa minat berwirausaha responden memiliki kecenderungan yang tinggi (positif). Namun demikian, berdasarkan skor maksimal (50) dan minimal (28) subjek diperoleh standar deviasi hipotetik sebesar 3,667 yang lebih rendah daripada standar deviasi empirik yang berarti bahwa minat berwirausaha responden memiliki variasi yang tinggi atau cenderung tidak seragam. Dengan kata lain, ada beberapa responden yang memiliki minat yang tinggi dan ada juga yang rendah. Hasil pengkategorian menunjukkan bahwa minat berwirausaha dari 110 responden umumnya berada pada kategori "sedang" (40,0\%).

\section{Analisis Regresi}

Hasil analisis regresi disajikan pada Tabel 11 berikut ini:

Tabel 11. Hasil analisis regresi minat berwirausaha mahasiswa

\begin{tabular}{|c|c|c|c|c|}
\hline \multicolumn{5}{|c|}{ Model Summary } \\
\hline Model & $\mathrm{R}$ & $\begin{array}{c}\mathrm{R} \\
\text { Square }\end{array}$ & $\begin{array}{l}\text { Adjusted } \\
\text { R Square }\end{array}$ & $\begin{array}{l}\text { Std. Error of } \\
\text { the Estimate }\end{array}$ \\
\hline 1 & $.660^{a}$ & .436 & .420 & 3.852 \\
\hline \multicolumn{5}{|c|}{$\begin{array}{l}\text { a. Predictors: (Constant), Pendidikan_Kewirausahaan, } \\
\text { Lingkungan_Keluarga, Ekspektasi_Pendapatan }\end{array}$} \\
\hline \multicolumn{5}{|c|}{ ANOVA $^{b}$} \\
\hline Model & & $\mathrm{df}$ & $\mathrm{F}$ & Sig. \\
\hline $\operatorname{Re}$ & ressio & & 3 & 7.327 \\
\hline
\end{tabular}




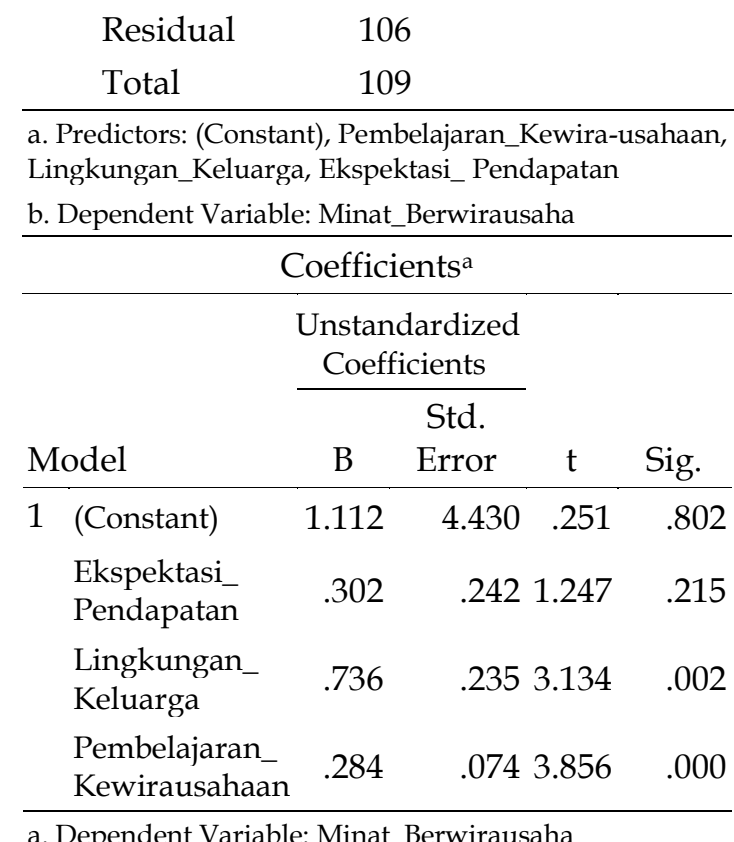

Nilai $R$ Square 0,436 pada Tabel 11 mengindikasikan bahwa 43,6\% minat berwirausaha responden dipengaruhi oleh faktor ekspektasi pendapatan, dukungan keluarga, dan pembelajaran kewirausahaan, selebihnya $56,4 \%$ dipengaruhi oleh faktor selain variabel yang diteliti. Variabel lain yang diduga berpengaruh terhadap minat berwirausaha responden, antara lain modal, waktu, dan bidang ilmu yang ditekuni. Hal ini didasarkan pada jawaban responden pada pertanyaan isian kuesioner yang pada umumnya menyebutkan bahwa ketiga faktor tersebut merupakan penghambat untuk memulai berwirausaha.

Mahasiswa STITEK Balik Diwa Makassar umumnya berasal dari pesisir dengan latar belakang keluarga yang secara ekonomi relatif terbatas sehingga ketersediaan modal dan peralatan untuk berwirausaha juga terbatas. Kegiatan perkuliahaan dengan berbagai aktivitasnya membuat responden merasa kesulitan dalam mengelola waktu antara kegiatan kuliah dengan kegiatan wirausaha. Bidang ilmu responden yang berfokus pada bidang perikanan dengan karakteristik produk yang memiliki risiko tinggi juga diduga menjadi variabel lain yang mempengaruhi minat mahasiswa berwirasaha. Manajemen waktu, tenaga, dan uang dalam kegiatan wirausaha merupakan faktor penting karena mahasiswa selain berwirausaha juga dituntut untuk menyelesaikan studi dengan baik (U'rfillah dan Muflikhati, 2017)

Nilai Sig. Anova pada Tabel 11 adalah 0,000 lebih kecil dari 0,05 yang mengindikasikan bahwa ekspektasi pendapatan dan lingkungan keluarga serta pembelajaran kewirausahaan secara bersama-sama mempengaruhi minat responden untuk berwirausaha. Minat reponden yang umumnya berada pada kategori "sedang" (Tabel 10) merupakan hasil interaksi dari faktor pembelajaran kewirausahaan serta ekspektasi pendapatan dan keluarga juga berada pada kategori "sedang" (Tabel 7, 8, dan 9).

Berbagai studi menunjukkan bahwa minat mahasiswa untuk berwirausaha dipengaruhi oleh berbagai faktor yang berkembang sesuai dengan daya pengaruh dan interaksi berbagai faktor tersebut, termasuk ketiga variabel yang diteliti. Pembelajaran kewirausahaan serta lingkungan keluarga dan ekspektasi pendapatan berpengaruh secara signifikan terhadap minat mahasiswa untuk berwirausaha (Azzam, 2016; Fahmi dan Amanda, 2017; Suarjana dan Wahyuni, 2017; Aryaningtyas dan Palupiningtyas, 2017; Pujiastuti dan Filantrovi, 2018; Listiawati, dkk., 2020). Pembelajaran kewirausahaan, 
lingkungan keluarga, dan ekspektasi pendapatan yang semakin baik akan berdampak terhadap minat berwirausaha mahasiswa yang semakin meningkat (Azzam, 2016).

Nilai Sig. dari masing-masing variabel (Tabel 11) sebesar 0.215, 0,002, dan 0,000 yang mengindikasikan bahwa secara parsial ekspektasi pendapatan tidak berpengaruh signifikan (Sig.>0.05) terhadap minat berwirausaha, tetapi minat berwirausaha responden dipengaruhi secara signifikan (Sig. $<0,05)$ oleh dukungan lingkungan keluarga dan aktivitas pembelajaran kewirausahaan.

Berdasarkan nilai koefisien pada Tabel 11 diperoleh persamaan regresi:

$$
\mathrm{Y}=1.112+0.302 \mathrm{X}_{1}+0.736 \mathrm{X}_{2}+0.284 \mathrm{X}_{3}
$$

Persamaan regresi menunjukkan bahwa seluruh nilai koefisien bernilai positif sehingga dapat dinyatakan bahwa semakin meningkat ekspektasi pendapatan $\left(\mathrm{X}_{1}\right)$, dukungan keluarga $\left(X_{2}\right)$, dan aktivitas pembelajaran kewirausahaan $\left(X_{3}\right)$, maka semakin tinggi minat berwirausaha responden. Nilai konstanta menunjukkan bahwa apabila ekspektasi pendapatan, dukungan lingkungan keluarga, dan aktivitas pembelajaran kewirausahaan tidak berubah, maka minat berwirausaha meningkat 1,112.

Koefisien regresi dari masingmasing variabel (Tabel 11) mengindikasikan bahwa jika ekspektasi pendapatan, dukungan lingkungan keluarga, dan aktivitas pembelajaran kewirausahaan ditingkatkan masingmasing sebesar 1 poin dengan asumsi variabel lain tidak berubah, maka minat berwirausaha mahasiswa akan meningkat masing-masing sebesar 0.302, 0,736, dan 0,284.

Besaran pengaruh kausal setiap variabel menunjukkan bahwa pembelajaran kewirausahaan memberikan kontribusi terendah terhadap minat berwirausaha responden. Hasil yang sama pada beberapa studi yang melaporkan bahwa konstribusi pembelajaran kewirausahaan terhadap minat mahasiswa untuk berwirausaha juga relatif rendah. Koefisien regresi pembelajaran kewirausahaan terhadap minat berwirausaha pada mahasiswa Jurusan Akuntansi Politeknik Negeri Bali hanya sebesar 0,182 (Suarjana dan Wahyuni, 2017), nilai koefisien 0,248 pada mahasiswa FKIP Universitas Sebelas Maret Surakarta (Listiawati, dkk., 2020), nilai koefisien 0,271 pada mahasiswa STIE Bank BPD Jawa Tengah (Pujiastuti dan Filantrovi, 2018), dan nilai koefisien 0,372 pada mahasiswa STIEPARI Semarang (Aryaningtyas dan Palupiningtyas, 2017).

Mengacu pada kontribusi pembelajaran kewirausahaan pada minat berwirausaha mahasiswa yang umumnya rendah, maka perlu dilakukan evaluasi pada proses pembelajaran yang diterapkan. Khusus di STITEK Balik Diwa Makassar yang merupakan perguruan tinggi yang berfokus pada bidang ilmu perikanan dan kelautan, evaluasi secara menyeluruh harus segera dilakukan agar minat mahasiswa untuk berwirausaha lebih meningkat. Hal ini sangat penting mengingat potensi perikanan dan kelautan di Sulawesi Selatan pada khususnya dan Indonesia pada umumnya menuntut sumberdaya manusia yang memiliki 
kemampuan untuk memanfaatkan potensi tersebut sebagai sumber pendapatan dan kesejahteraan melalui kegiatan wirausaha.

Jika lulusan diarahkan untuk menjadi entreprenur, maka menjadi sangat penting bagi institusi pendidikan untuk menerapkan kurikulum yang mampu memfasilitasi dan menumbuhkan semangat kewirausahaan (Indarti dan Rostiani, 2008). Mata kuliah Kewirausahaan di STITEK Balik Diwa Makassar telah dimasukkan dalam kurikulum sejak tahun 2005 sebagai Mata Kuliah Perilaku Berkarya. Capaian pembelajaran dari mata kuliah wajib yang disajikan pada Semester 6 ini diharapkan mahasiswa dapat menguasai pengetahuan dan keterampilan (hardskills dan softskills) kewirausahaan sehingga terbentuk karakter pengusaha muda yang kreatif, inovatif, mandiri dan mampu mengambil risiko yang terukur dalam memanfaatkan berbagai potensi ekonomi pada sektor perikanan dan kelautan.

Data penilaian pembelajaran kewirausahaan pada Tabel 9 menunjukkan $34.5 \%$ responden menilai "sedang", 27.3\% menilai "tinggi", 25.5\% menilai "rendah", 9.1\% menilai "sangat tinggi", dan 3.6 yang menilai "sangat rendah". Sebaran data ini menunjukkan bahwa secara akumulatif tidak sedikit responden $(29.1 \%)$ yang menilai "rendah" dan "sangat rendah". Indikator variabel pembelajaran kewirausahaan yang umumnya masih "rendah" adalah metode dan fasilitas pembelajaran. Kedua indikator ini perlu mendapatkan perhatian khusus dalam pembelajaran agar minat mahasiswa untuk berwirausaha pada saat lulus nanti lebih meningkat.

Upaya untuk meningkatkan minat mahasiswa dan mengarahkannya untuk berwirausaha pada bidang perikanan dan kelautan bukanlah hal yang mudah. Wirausaha pada bidang ini bersifat khas dan spesifik serta memerlukan penanganan khusus karena produknya memiliki karakteristik yang mudah mengalami kerusakan dan bersifat musiman sehingga memiliki risiko bisnis yang tinggi. Produk perikanan dengan kadar air dan protein yang tinggi sangat rentan terhadap kerusahan sehingga perlu penanganan yang tepat untuk menjaga kualitasnya (Abraha, dkk, 2018; Nagarajarao, 2016). Oleh karena itu. metode pembelajaran kewirausahaan harus memberikan pengetahuan (kognitif), sikap (afektif), keterampilan (psikomotorik), dan pola pikir (mindset) secara terintegrasi sehingga mahasiswa memiliki keberanian menantang risiko secara terukur dalam memanfaatkan berbagai potensi ekonomi sektor perikanan dan kelautan yang tersebar dari hulu sampai hilir. Keberanian dalam menanggung risiko dapat mempengaruhi minat berwirausaha secara personal karena terkait kesediaan menanggung berbagai potensi risiko berkaitan dengan kesempatan dan tindakan berusaha yang dilakukanya (Azzam, 2016; Kasmir. 2013; Alma, 2016; Riyanti, 2003).

Metode pembelajaran juga harus dikembangkan melalui kerjasama dan kolaborasi dengan para pemangku kepentingan, khususnya lingkungan keluarga. Variabel lingkungan 
keluarga berdasarkan persamaan regresi memiliki kontribusi tertinggi (0.736) dalam membentuk minat berwirausaha mahasiswa STITEK Balik Diwa Makassar. Terdapat banyak referensi dan penelitian yang menginformasikan bahwa lingkungan keluarga memiliki peran strategis dalam menumbuhkan minat berwirausaha mahasiswa. Sikap beserta aktivitas anggota keluarga akan mempengaruhi minat berwirausaha, baik secara langsung maupun tidak langsung apabila lingkungan keluarga menciptakan pengaruh positif terhadap minat tersebut (Pihie, 2009). Pendidikan berwirausaha pada hakekatnya berlangsung sejak usia dini dalam lingkungan keluarga (Aprilianty, 2012). Orang tua yang berwirausaha pada bidang tertentu merupakan sumber inspirasi bagi anak untuk menjadi wirausahawan, pada bidang yang sama (Hisrich, dkk., 2005).

Berdasarkan hasil tracer study terhadap lulusan STITEK Balik Diwa Makassar yang orangtuanya pelaku utama perikanan menunjukkan bahwa secara umum lulusan masih memilih bekerja menjadi karyawan di perusahaan atau instansi perikanan dan kelautan. Bahkan ada lulusan yang bidang pekerjannya kurang selaras dengan bidang ilmunya. Lulusan yang memilih untuk berwirausaha pada bidang perikanan dan kelautan masih relatif rendah, bahkan ada yang berwirausaha pada bidang non perikanan. Hal ini mengindikasikan bahwa lingkungan keluarga belum secara optimal membentuk minat anak untuk berwirausaha di bidang perikanan dan kelautan. Kondisi ini diduga disebabkan oleh berbagai faktor, antara lain wirausaha yang dilakukan oleh orangtua mahasiswa umumnya masih bersifat tradisional yang belum menghasilkan kesejahteraan sehingga membuat minat mahasiswa untuk melanjutkan atau mengembangkan wirausaha yang dikembangkan orangtuanya menjadi rendah.

Pada prinsipnya, orangtua mahasiswa yang bekerja sebagai pembudidaya atau nelayan telah melakukan kegiatan kewirausahaan meskipun belum menerapkan model kewirausahaan yang baik. Hal ini berarti bahwa sebenarnya lingkungan keluarga telah mendukung penumbuhan jiwa dan aktivitas wirausaha mahasiswa sejak dini. Wirausaha keluarga tersebut perlu mendapatkan penguatan untuk mengembangkan jiwa dan aktivitas wirausaha mahasiswa melalui pembelajaran kewirausahaan. Pada konteks ini, metode pembelajaran kewirausahaan harus mampu menumbuhkembangan jiwa dan aktivitas kewirausahaan perikanan yang berbasis aktivitas lingkungan keluarga yang didukung oleh ilmu pengetahuan dan teknologi. Dengan demikian, mahasiswa setelah lulus dapat menjadi entrepreneur yang dapat melanjutkan bahkan mengembangkan kegiatan wirausaha yang telah dijalankan oleh keluarga berdasarkan perkembangan ilmu pengetahuan dan teknologi. Pada saat bersamaan, lingkungan keluarga mahasiswa harus menjadi objek kegiatan penelitian dan pengabdian yang dilakukan oleh STITEK Balik Diwa Makassar untuk membantu pengembangan kewirausahannya. 
Indikator lain selain metode pembelajaran yang perlu mendapatkan perhatian khusus dalam meningkatkan minat mahasiswa berwirausaha adalah fasilitas pembelajaran. STITEK Balik Diwa Makassar melalui institusi dan dosen telah menyediakan berbagai fasilitas pendukung pembelajaran kewirausahaan, antara lain Pembentukan Pusat Karier dan Kewirausahaan Mahasiswa (Pusat KKM), Pusat Inkubator Bisnis (PIB), pendirian koperasi mahasiswa, pembentukan kelompok wirausaha mahasiswa, pelaksanaan Program Belajar Bekerja Terpadu (PBBT) dan Program Pengembangan Kewirausahaan (PPK), kerjasama UMKM, serta pelatihan dan seminar kewirausahaan. Fasilitas sarana dan prasarana serta berbagai program tersebut diarahkan untuk memberikan pengalaman berusaha kepada mahasiswa. Namun demikian, berdasarkan hasil analisis data, fasilitas pembelajaran kewirausahaan tersebut memiliki nilai yang rendah dalam memicu minat berwirausaha mahasiswa. Hal ini diduga disebabkan oleh faktor keaktifan mahasiswa dan faktor keberlanjutan program. Oleh karena itu, perlu upaya-upaya yang dapat meningkatkan motivasi mahasiswa agar terlibat secara aktif dalam memanfaatkan berbagai fasilitas yang ada. Peran dosen pengampu mata kuliah dan dosen pembimbing akademik serta pengelola lembaga yang terkait dengan kewirausahaan perlu dioptimalkan untuk meningkatkan keaktifan mahasiswa melakukan konsultasi dan implementasi pengembangan minat, bakat, dan kegiatan kewirausahaan, termasuk keberlanjutan kegiatan wirausaha setelah menyelesaikan studi di STITEK Balik Diwa Makassar. Upaya lain yang perlu dilakukan untuk meningkatkan minat kewirausahaan adalah menindaklanjuti Program Merdeka BelajarKampus Merdeka (MBKM) dari Kementerian Pendidikan dan Kebudayaan. Program ini merupakan reformasi bentuk pembelajaran dalam dunia pendidikan yang memberikan hak kepada mahasiswa untuk melakukan kegiatan pembelajaran di luar kampus. Salah satu dari delapan kegiatan pembelajaran diluar kampus adalah program wirausaha. STITEK Balik Diwa Makassar telah menetapkan regulasi Merdeka Belajar yang mengakomodasi kegiatan kewirausahaan mahasiswa. Pusat Inkubator Bisnis (PIB) diharapkan dapat mengintegrasikan program ini dengan kegiatannya. Program studi juga diharapkan dapat memfasilitasi mahasiswa melalui kerjasama dengan mitra industri dalam mencitakan model pembelajaran kewirausahaan dengan sistem praktek langsung. Mahasiswa selama menjalankan program wirausaha tersebut harus mendapatkan pembimbingan dari dosen, pakar wirausaha atau pengusaha yang telah berhasil. Program ini diharapkan dapat mendorong pengembangan minat wirausaha mahasiswa sehingga dapat mengembangkan kegiatan wirausaha setelah lulus di perguruan tinggi.

\section{KESIMPULAN}

Ekspektasi pendapatan dan dukungan lingkungan keluarga serta pembelajaran kewirausahaan secara 
bersama-sama mempengaruhi $43,6 \%$ minat berwirausaha mahasiswa, selebihnya 56,4\% dipengaruhi oleh faktor diluar variabel yang dikaji. Dukungan lingkungan keluarga, ekspektasi pendapatan, dan pembelajaran kewirausahaan yang semakin meningkat berbanding lurus dengan minat berwirausaha mahasiswa STITEK Balik Diwa Makassar. Persamaan regresi minat berwirausaha mahasiswa adalah $\mathrm{Y}=$ $1.112+0.302 \mathrm{X}_{1}+0.736 \mathrm{X}_{2}+0.284 \mathrm{X}_{3}$ Metode pembelajaran dan fasilitas pembelajaran perlu mendapatkan perhatian khusus dalam meningkatkan minat mahasiswa untuk berwirausaha. Metode pembelajaran kewirausahaan harus mampu menumbuhkembangan jiwa dan aktivitas kewirausahaan yang berbasis aktivitas lingkungan keluarga yang didukung oleh ilmu pengetahuan dan teknologi. Mahasiswa harus selalu dimotivasi agar terlibat secara aktif dalam memanfaatkan berbagai fasilitas pembelajaran kewirausahaan. Program Merdeka Belajar-Kampus Merdeka (MBKM) dari Kementerian Pendidikan dan Kebudayaan perlu segera ditindaklanjuti melalui pengembangan bentuk pembelajaran Program Wirausaha.

\section{UCAPAN TERIMA KASIH}

Terima kasih kepada Deputi Bidang Penguatan Riset dan Pengembangan Kementerian Riset dan Teknologi/BRIN atas dana Hibah Penelitian Dosen Pemula Tahun Anggaran 2020.

\section{DAFTAR PUSTAKA}

Abraha B., Admassu H., dan Mahmud A. (2018). Effect of Processing Methods on Nutritional and PhysicoChemical Composition of Fish: a Review. MOJ Food Process Technol. 6(4): 376-382.

Alma, B. (2016). Kewirausahaan untuk Mahasiswa dan Umum. Bandung: CV. Alfabeta.

Aprilianty, E. (2012). Pengaruh Kepribadian Wirausaha, Pengetahuan Kewirausahaan, dan Lingkungan terhadap Minat Berwirausaha Siswa SMK. Jurnal Pendidikan Vokasi. 2(3): 311-324.
Aryaningtyas, A.T., dan Palupiningtyas D. (2017). Pengaruh Pendidikan Kewirausahaan dan Dukungan Akademik terhadap Niat Kewirausahaan Mahasiswa (Studi pada Mahasiswa STIEPARI Semarang). Jurnal Ilmiah Manajemen dan Bisnis. 18(2): 140-152.

Azwar, S. (2012). Penyusunan Skala Psikologi. Yogyakarta: Pustaka Pelajar.

Azzam, H. (2016). Pengaruh Ekspektasi Pendapatan, Lingkungan Keluarga dan Pendidikan Kewirausahaan terhadap Minat Mahasiswa Akuntansi untuk Berwirausaha (Studi Kasus pada Mahasiswa Akuntansi Unismuh Jember). Jurnal Fakultas Ekonomi Universitas Muhammadiyah Jember. Juli. 1-12. 
Djaali. (2012). Psikologi Pendidikan. Jakarta: Bumi Aksara

Fahmi, R., dan Amanda, T. (2017). Pengaruh Pembelajaran Kewirausahaan terhadap Minat Berwirausaha Mahasiswa. Jurnal Ekonomi dan Bisnis Islam. 2(1): 33-42.

Hantoro, S. (2005). Kiat Sukses Berwirausaha. Yogyakarta: Adicita Karya Nusa.

Hisrich, Robert D., Peters, Michael P., and Shepherd, D.A. (2005). Entrepreneurship (6th ed). New York: The McGraw-Hill Companies Inc.

Indarti, N., dan Rostiani, R. (2008). Intensi Kewirausahaan Mahasiswa: Studi Perbandingan antara Indonesia, Jepang, dan Norwegia. Jurnal Ekonomika dan Bisnis Indonesia. 23(4): 1-26.

Jati, W.R. (2015). Bonus Demografi sebagai Mesin Pertumbuhan Ekonomi: Jendela Peluang atau Jendela Bencana di Indonesia?. Populasi. 23(1): 1-19.

Kasmir. (2013). Kewirausahaan. Jakarta: Rajawali Pers.

Listiawati, M., Dyah C.S.I., dan Susantiningrum. 2020. Pengaruh Pembelajaran Kewirausahaan dan Pemanfaatan Media Sosial terhadap Minat Berwirausaha Mahasiswa FKIP UNS. Jurnal Kewirausahaan dan Bisnis. 25(1): 27-36.

Maryati, S. (2015). Dinamika Pengangguran Terdidik: Tantangan Menuju Bonus Demografi di Indonesia. Journal of Economic and Economic Learning. 3(2): $124-136$.

Nagarajarao, R. C. (2016). Recent Advances in Processing and Packaging of Fishery Products: a Review. Aquatic Procedia. 7: 201213.

Permatasari, A., dan Agustina, A. (2018). Entrepreneurial Behaviour among Undergraduate Business, Social and Engineering Students: A Case of Private Indonesian University. Jurnal Manajemen Indonesia. 18(2) : 94-110.

Pihie, Z.A.L. (2009). Entrepreneurship as a Career Choice: An Analysis of Entrepreneurial Self-Efficacy and Intention of University Students. European Journal of Social Sciences. 9(2).

Pujiastuti, Y., dan Filantrovi, E.W. (2018). Gambaran Minat Kewirausahaan Mahasiswa (Studi terhadap Mahasiswa STIE Bank BPD Jateng). Jurnal Manajemen. 15(2): 169-180.

Riyanti, B. (2003). Kewirausahaan dari Sudut Pandang Psikologi Kepribadian. Jakarta: Gramedia.

Suarjana, A.A.G.M., dan Wahyuni, L.M. 2017. Faktor Penentu Minat Berwirausaha Mahasiswa (Suatu Evaluasi Pembelajaran). Jurnal Kewirausahaan dan Bisnis. 13(1): 11-22.

Sugiyono. (2011). Metode Penelitian Kuantitatif Kualitatif dan RED. Bandung: Alfabeta.

Sutanto, A. (2002). Kewiraswastaan. Jakarta: Ghalia Indonesia. 
Syah, M. (2011). Psikologi Belajar.

Jakarta: Rajawali Pers.

U'rfillah, U., dan Muflikhati, I. (2017). Motivasi Berwirausaha,

Manajemen Waktu, Manajemen

Keuangan, dan Prestasi

Akademik pada Mahasiswa

Wirausaha. Jur. Ilm. Kel. E Kons. 10(1): 71-82.

Utami, C.W. (2017). Attitude Subjective Norm, Perceived Behaviour, Entrepreneurship Learning and Self Efficacy Toward Entrepreneurial Intention University Student in Indonesia. European Research Studies Journal (ERSJ). 20(2A): 475-495.

Walgito, B. (2004). Pengantar Psikologi Umum. Yogyakarta: Andi Offset.

Zimmerer, T.W., Scarborough, N.M., and Wilson, D. (2002). Essentials of Entrepreneurship and Small Business Management. New Jersey: Prentice-Hall. 